\title{
Kindergarten in Ontario - An Exceptional Case of a Publicly Funded Early Childhood Education Since 1883
}

\author{
Danuta Wloka \\ Queen's University
}

\begin{abstract}
Ontario has the distinction of having the longest and the richest history of public kindergarten in Canada. Ontario's kindergarten is an exception in the field of publicly funded early childhood care and education in Canada, where the care and education of preschool-aged children has not been recognized as the government's responsibility. This article traces the development of Ontario's public kindergarten from its inception in 1883 to the current Full-Day Early Learning-Kindergarten Program. It identifies the evolving characteristics of kindergarten, trends, and paradigmatic changes in the analyzed period by using a longue durée approach as per Fernand Braudel. It explores the context of each historical phase of Ontario's kindergarten development, the intersection of political agendas, ideologies, and economic and pragmatic considerations that were impacting kindergarten policies.
\end{abstract}

Keywords: kindergarten, childcare, early childhood education, early years education policy, longue durée history 


\section{Les écoles maternelles en Ontario - Le cas exceptionnel d'une initiative d'éducation de la petite enfance subventionnée par le gouvernement depuis 1883}

\section{Résumé}

L'Ontario est la province canadienne qui a la plus ancienne et la plus riche histoire d'éducation maternelle et de soins aux enfants d'âge préscolaire au Canada. Les maternelles ontariennes font exception au Canada dans le domaine des soins et de l'éducation de la petite enfance subventionnés par des fonds publics dans la mesure où ces services ne relèvent pas du gouvernement dans les autres provinces. Cet article retrace le développement de la maternelle publique en Ontario depuis son début en 1883 jusqu'à l'actuel Programme d'apprentissage à plein temps de la petite enfance. En privilégiant la longue durée tel que prôné par Fernand Braudel, l'auteur analyse l'évolution des caractéristiques des maternelles, les tendances et les changements paradigmatiques, sur la période étudiée. L'article explore le contexte de chaque phase historique du développement de la maternelle Ontarienne, ainsi que les intersections des agendas politiques, des idéologies et des considérations économiques et pragmatiques qui ont eu un impact sur les politiques des maternelles.

Mots-clés: école maternelle, éducation préscolaire, politique éducative pour la petite enfance, la longue durée

\section{El Kindergarten en Ontario: un caso excepcional de educación infantil pública desde 1883}

\section{Resumen}

Ontario tiene la distinción de tener la historia de la educación infantil pública más larga y rica de Ontario. El kindergarten de Ontario es una excepción en Canadá, donde el cuidado y la educación de los/las niñas/os no ha sido reconocido como

responsabilidad del gobierno. Este artículo rastrea el desarrollo de la educación infantil pública en Ontario desde su comienzo en 1883, hasta el programa actual conocido como Full-Day Early Learning-Kindergarten Program. Se identifican las características evolutivas del kindergarten así como las tendencias y cambios paradigmáticos en el período analizado usando un enfoque "longue durée" (Fernand Braudel). El artículo explora el contexto de cada fase histórica del desarrollo de la educación infantil en Ontario, la intersección de agendas políticas e ideológicas, así como consideraciones 
económicas y pragmáticas que tuvieron un impacto en las políticas relacionadas al kindergarten.

Palabras clave: kindergarten, educación infantil, políticas educativas para educación infantil, historia "longue durée"

\section{Introduction}

Kindergarten originated in 1837 in Germany-Prussia with Friedrich Froebel's idea of education, in which children learn by engaging in developmental, play-based activities under the direction of a specially trained teacher. Play was central to Froebel's concept of learning, and he designed his curriculum using the child's natural inclination to play and imitate. He devised teaching materials (Gifts) and activities (Occupations) to help children understand certain concepts and develop manual dexterity (Corbett, 1989).

Beginning in 1883, Ontario was the first, and for many decades the only province in Canada to continuously provide kindergarten as part of a public education. In 2010, Ontario made another innovative policy decision and introduced a new model of kindergarten, the Full-Day Early Learning-Kindergarten (FDELK), extended to a twoyear full day play-based program instructed by a kindergarten teacher and an early childhood educator. Since then, following Ontario's steps, other territorial/provincial governments started introducing a full day kindergarten in publicly funded schools (Friendly et. al, 2018).

Ontario's public kindergarten is an exception in Canada, where the care and education of preschool-aged children has not been recognized as the government's responsibility. Canadian provinces and territories have lacked universal childcare and early education programs. The existing ones are a fragmented and chaotic mix of early childhood services operated by different providers under various auspices (Pascal, 2009; Friendly et al., 2018). Ontario is a leader in Canada in the field of publicly funded early childhood education and represents an interesting case of an early childhood program that has gone through many stages before reaching its current point. Although Ontario's kindergarten has an almost 150-year history, it is very scarcely represented in literature, especially its development between the 1960s and 2010. This historical analysis adds to the existing literature by tracing the development of Ontario's public kindergarten from its inception to the current program.

Historical perspective is needed for understanding the foundations of the current FDELK, because "past and present illuminate each other reciprocally" (Braudel, 1980, p.37). The longue durée approach as put forward by historian Fernand Braudel (1980) allows the identification of the evolving characteristics of kindergarten, some trends and patterns, and the points of conjunctures over the studied period in order to draw conclusions from them. Quentin Skinner's (1969) theory of interpretation is helpful in 
examining the original texts and documents, and in exploring how the author's intentionality ties with the historical context and how different forces (the intersection of political agendas, ideologies, social, economic, and pragmatic considerations) influenced kindergarten policies. Skinner's theory calls for placing the texts in their historical setting and avoiding the retrospective imposition of modern conceptions. Skinner argued that the text should be interpreted considering its illocutionary (communicative) and not locutionary (semantic) meaning. His idea of meaning focuses on the intention of the author of the text. He argues that "historical differences over fundamental issues may reflect differences of intention and convention" rather than differences in values (Skinner, 1969, p. 52).

\section{James Hughes and First Public School Kindergarten in Toronto}

The first kindergarten in a Canadian public school opened in Toronto in 1883 as a result of many years of tireless promotion of kindergarten by James Hughes, chief inspector for public schools in Toronto. Hughes was first introduced to kindergarten in the United States, where Froebel's idea of kindergarten was already adopted and adjusted to the needs of their society (Prochner, 2000; Wollons, 2000; Shapiro, 1983). In 1876 he visited a school in New York, and the teacher from that school, Ada Marean, was delegated to help establish kindergarten in Toronto (Carter, 1966).

Over the next few years, Hughes and Marean - with the support of Susan Blow, an orthodox Froebelian and a director of kindergartens in St. Louis, Missouri-were advocating for public kindergarten in Toronto (Prochner, 2009). When they succeeded in 1883 and the first public kindergarten in Canada was opened in Louisa Street Public School, it was met with great enthusiasm. In the following years, however, enrollment was fluctuating considerably - from 80 children initially enrolled to only six in 1886, but increasing steadily after that (Prochner, 2009).

Hughes was convinced of the advantages of kindergarten education, and the obligation of each school board to provide kindergarten to all children as part of the public education system. He wrote: "Attempts to treat kindergarten as a separate institution, having aims and methods of its own different from those which should prevail in other schools, have often in America and Germany proved unsuccessful" (Hughes, 1897, p. x). In his speech he stated:

The State has no right to assume the duty of giving an education unless it provides the best possible training and culture for its children. It is unjust .... If the kindergarten be truly the most stimulating educational process at a certain period of a child's development, then all children are entitled to its advantages. (Hughes in Carter, 1966, p. 314) 
However, as long as material fees were charged by school boards, kindergarten was popular mostly among the middle class (Prochner, 2009). From 1886, Hughes tried to have the fees waived so the children who most likely needed the benefit of kindergarten could also attend, and the fees were eventually eliminated in 1892 (Mathien, 2001). The Public School Act of 1891, which includes kindergarten in its decrees, states: "All Public Schools shall be free schools, and every person between the age of 5 and twenty-one years shall have the right to attend some school. Pupils may attend Kindergarten Schools from four to seven years of age" (McMurrich and Roberts, 1894).

It is not surprising that Hughes, an active Methodist, was attracted to Froebel's ideas and his concept of the unity of humans, nature, and God. Froebel understood education as growth from within the child that leads to harmony with God, humankind, and nature (Bruno-Jofré \& Jover, 2011). The growing child would reflect God's image in self-activity and creativity that would remain for life. He wrote:

By education, then, the divine essence of man should be unfolded, brought out, lifted into consciousness, and man himself raised into free, conscious obedience to the divine principle that lives in him, and to a free representation of this principle in his life. (Froebel, 1908, pp. 4-5)

Conversely, Hughes states in his creed that God is "the essence of life which gives it the power of evolution to higher life, and the center of universal unit," so the goal for education should be "to aid in the complete development of individuality as the true basis for the community of humanity and the unity of humanity with God" (Bruno-Jofré \& Jover, 2013, p. 7).

Although kindergarten elsewhere was going through changes in the first two decades of the 20th century, in Toronto it differed little from its initial approach and from Froebel (Prochner, 2009), probably because of a very strong leadership and the influence of James Hughes and his wife, the orthodox Froebelians. Owing to their passionate work and efforts, Toronto was the leading force in introducing kindergarten throughout Ontario and across Canada. The success of this leadership should also be seen in the context of the economic and demographic conditions which were very favorable for Toronto at the end of the 19th century. Julie Mathien (2001) notes "Toronto's economic preeminence among all of the nation's cities .... Toronto's growth in both capital and gross and net value of production between 1900 and 1921 was both impressive and steady" (Mathien, 2001, p. 1). Mathien adds that "Neil Sutherland identifies Toronto as the major location for childhood reform" (Mathien, 2001, p. 3). Toronto's middle class city dwellers, "first expressed the new ideas on childhood and family life and organized the many associations, campaigns and the like which tried to put the theory into practice" (Sutherland in Mathien, 2001, p. 4). 


\section{Instituting Kindergarten in the Province}

In 1885, the Ontario Public School Act issued an amendment allowing funding for school boards that wished to open kindergartens and provide kindergarten teacher's training (Prochner, 2009). In 1886 the Ontario Minister of Education issued a Departmental Circular urging school boards to establish kindergartens across the province (Corbett, 1989). The document promoted a unified school system starting from an early age and recognized the value of qualified kindergarten teachers called kindergarteners (Corbett, 1989).

Kindergarten was formally legislated in Ontario in 1886, and in 1887 the system of grants was put in place (Corbett, 1989). Since then, kindergartens grew rapidly-in 1895 there were kindergartens in 40 public schools (Corbett, 1989) and by 1900 there were 166 kindergartens in Ontario attended by over 11,000 children (Johnson, 1968). The school boards initially admitted children from age five to seven, but the age range was later narrowed (Prochner, 2000). In 1892, the Kindergarten Section of the Ontario Educational Association was formed (Corbett, 1989).

In 1886, kindergarten training was offered at the Normal Schools in Toronto and Ottawa, and the Inspector of Kindergartens for the province was appointed. The inspections found that where the teachers had no specialized training, the program looked more like primary classes with the exception of the materials used (Corbett, 1989). The early curriculum was Froebelian and it was supposed to help the child grow; growth became the main slogan and goal of the early kindergarten (Corbett, 1989). The program was expected to be a link between home and school, and provide educational foundations through the child's play: "The kindergarten preserves the freedom and play spirit of early childhood and at the same time prepares the child to be an intelligent, orderly, and industrious pupil of the school" (Ontario Department of Education, 1908).

Early kindergartens often experienced difficulties with following the true Froebelian philosophy. One of the reasons was that they were introduced in Ontario schools where the traditional practice was for the teacher to instruct and the children to listen (Corbett, 1989). Froebel's method was the reverse of that practice-the child was engaged in self-activity, while the teacher was only observing and guiding. The children were to develop and grow from within during this self-activity, which was play. In a letter written to the graduating teachers' class Hughes wrote:

In all your teaching, think of the child, not of the knowledge. The child is the power; knowledge is not power. You must make the child your chief study; not the knowledge you are to give him and how to give it to him. (Hughes, 1890, p. 10)

Not all educators had the same understanding of these principles and some directed lessons were also used in kindergartens. In some, children were told what to do: for example, instructed how to use Gifts and put the blocks together instead of 
discovering it themselves (Corbett, 1989). At that time, the value of play in a child's development was not widely understood and often criticized. By 1913, the Inspector of Kindergartens acknowledged that "the Froebelian method of play had met with defeat" (Corbett, 1989, p. 65). One reason for that was the high number of children in the room which limited the use of Froebel's principles to give individual children the freedom and attention they required. In some kindergartens there were up to 100 children in a class. The children were taught by a kindergartner and usually one assistant and unpaid students. Kindergartners wondered how they could maintain discipline and order, at the same time allowing children to execute their own plan for the activity as claimed by Froebel (Corbett, 1989). Thus, some began using more directed group activities, which lacked the joyful spirit of a true Froebelian kindergarten (Corbett, 1989).

Another reason for difficulties in following Froebelian philosophy was probably low attendance in the program, usually around 50\% (Mathien, 2001). The attendance was higher in the warmer months and lower in the winter; interestingly, when enrollment increased, the attendance decreased (Corbett, 1989). The cold weather during the winter probably prevented some children from walking to school, and parents were possibly concerned about health risks in overcrowded classrooms. This inconsistent attendance must have disrupted the participation in sequential and integrated Froebelian activities, also affecting children's outcomes.

In 1914, the new training for a Kindergarten-Primary Certificate was designed for teaching the combined kindergarten-primary class, which was a combination of a Grade 1 program with kindergarten activities (Corbett, 1989). The intention was to introduce the kindergarten philosophy into primary grades (Corbett, 1989). Instead, the opposite took place, and many kindergartens adopted the kindergarten-primary program (Corbett, 1989). From the 1930s to the 1950s, many kindergarten-primary classes became "reading classes" for children who attended kindergarten but were not ready to start Grade 1 (Corbett, 1989). In the 1950s, the kindergarten-primary classes were discontinued (Corbett, 1989).

\section{Kindergarten from 1920 to 1944}

The 1920s marked the beginning of important transformation of kindergarten, with plans to drastically modify the curriculum to include more academic work, replace the kindergarten supervisor with the primary supervisor, and link kindergarten with the school rather than with home (Prochner, 2000). The Primary Teacher Association, which previously supported kindergarten teachers in their efforts to establish their professional status, called for testing children for readiness before they could enter Grade 1 (Prochner, 2000). This call was not only undermining kindergarteners' professional qualifications but was directing kindergarten's goals toward academic preparation for school. The kindergartners, although initially fiercely opposed these 
plans, slowly succumbed and adapted to the primary school expectations (Prochner, 2000). Patty Smith Hill considered this a "survival" strategy to secure a permanent place in the school system, especially considering that throughout Canada kindergartens began experiencing a declining support (Prochner, 2000), due in part to new theories in psychology and education that criticized some Froebelian methods. The small Gifts and Occupations like sewing or weaving were criticized as unsuitable for young children whose large muscles develop before the development of their fine muscle coordination. Other toys like dolls, trains, puzzles, and playhouses were introduced, along with the free play idea that started replacing the guided play in Froebelian kindergarten. However, the conflicting ideas about play lasted until 1940s. Some kindergarten teachers continued to guide child's play, some fully adopted free play, and others were directing child's play (Corbett, 1989).

During World War II, kindergartens across Canada experienced a period of stagnation due to a growing need for full day childcare to support poor wage-earning mothers of young children who worked in war-related industries (Prochner, 2000). The number of working women in Canada increased from 200,000 in 1939 to 1,000,000 in 1944 (Prochner, 2000). The federal and provincial governments responded by opening wartime nurseries across the country. Establishment of junior kindergarten was legislated in 1939, but the first one opened in Ottawa in 1942; two years later Toronto started opening junior kindergarten programs (Ontario Teachers' Federation, 1973).

In 1944, the Ontario Department of Education issued a Program for Junior and Senior Kindergarten and Kindergarten-Primary Classes (Ontario, Department of Education, 1944). It was declaring: "following the age of Rousseau, Pestalozzi, and Froebel, during which the child had emerged as a control figure in the drama of education, ... kindergartens were established as part of a continuous training programme" (Ontario Department of Education, 1944, p. 6), and further, "It is the purpose of the following programme to make provision for those entering school at the permissive ages of three and four as those entering at five; to integrate the work of the kindergarten and that of the regular grades" (Ontario Department of Education, 1944, p. 8).

The main goals were socialization and the development of language. The half-day program started with free play followed by group games, singing or listening to stories, outdoor time, a served snack, and a rest time on pads placed on the floor (Corbett, 1989). The program in junior kindergarten was supposed to provide the experience and preparation for future instructions - the specific subjects were only suggesting how they form a natural part of a daily routine, but they cannot be separated in practice (Ontario Department of Education, 1944). Reading as a program component appeared for the first time in the kindergarten-primary class. 


\section{Kindergarten in the 1960s}

The 1944 program was revised in 1966. The 1966 revision was expanded from kindergarten to Grade 6 (Ontario Department of Education, 1966). Donna Varga suggests that this revision diminished the focus on the distinctive early years, focusing instead on general principles of education (Prochner, 2000). However, the "Kindergarten" document (Ontario Department of Education, 1966) does not stipulate any planned and teacher-directed activities in kindergarten except for speaking, auditory discrimination, and teacher reading to pupils. The document includes numerous citations from Pestalozzi and Froebel that emphasize the individual needs of each child that should be met by the program: "The nature of each child must determine all the details of his education and the educational institution must be so organized as to afford room for adaptation to the inclination and needs of the individual pupil" (Pestalozzi cited in Ontario Department of Education, 1966).

Junior and senior kindergarten are not separated in this document due to variations in children's readiness, but instead there are provisions for extended development (Ontario Department of Education, 1966). A child's readiness is defined as the moment when a child is able to experience success in a certain activity (Ontario Department of Education, 1966). "The school program should not become highly formalized and devoted to 'reading readiness' because, by its nature, readiness is broad in scope and comprehensive in development" (Ontario Department of Education, 1966, p. 88). Consequently, the program does not include reading in kindergarten.

In planning the kindergarten day, the document continues (subsequent to the 1944 program) to recommend enough time for relaxation in early years, including a nap. "If a child needs a rest, there should be provision for him to stretch out and sleep" (Ontario Department of Education, 1966, p. 12). It stipulates that a considerable part of a kindergarten day should be devoted to "activity time" which is defined as "a highly individualized experience which allows for much self-initiated, self-selected, selfdirected and self-evaluated activity" (Ontario Department of Education, 1966, p. 17). Citations from Froebel in this document are fully justified by its stance on child's development and the role of the teacher: "For each child, whatever his maturity and ability, the impulse comes from within to learn, to achieve, to find out, and to experience the joy and excitement of discovery" (Ontario Department of Education, 1966, p. 17). The teacher's role is:

to stimulate, to commend, to guide, to assist where she is needed, and to encourage links with the development of language. As she works with the children individually and in small groups, she has an excellent opportunity to observe each one and to gain information about his total growth and abilities. (Ontario Department of Education, 1966, p. 17) 
The use of the word "growth" creates another connection with Froebelian philosophy. Further associations appear in the subject program that starts with kindergarten and ends with junior grades in a horizontal format to reflect the continuity of education, as well as in the term "extended development" in suggestions for more advanced activities, as for Froebel the education was first and foremost for development not for learning.

Likewise, the "Living and Learning" report (Ontario Department of Education, 1968) states that

the kindergarten program should be free from the more formal aspects of the learning program. The Committee is convinced that its fundamental role as introductory experience to learning places it within the spectrum of the total school program, available to all children at the age of five. The term kindergarten should be retained, since it describes the function of this introductory period and serves to resist pressure to apply the rigors of schooling too early to young children (Ontario Department of Education, 1968, p. 81).

The rationale for keeping the name kindergarten is consistent with Froebel's idea of a "garden to grow" intended primarily for development and not for schooling.

The 1960s saw a change in the kindergarten program in America; the curriculum was becoming more academically oriented with prescriptive outcomes (Weber, 1969). This change was influenced by a political climate-the cold war and the launching of Sputnik by the Soviet Union in 1957. The perceived need for a scientific advance to surpass the Russians in space and technology was calling for a change in the education system (Shapiro, 1983). To some, an early academic start, beginning in kindergarten, was the answer to this call (Shapiro, 1983). There is no indication, however, that Ontario's kindergarten in the 1960s was influenced by this urge to make the program academically oriented. There was, however, a significant increase in the number of schools offering kindergarten and children attending them. In the 1960s, education was the main focus on the social and political agenda, and the largest single budget item in the public sector (Ontario, Royal Commission on Learning, 1994). In the 1960s, kindergartens started to be established in rural areas mainly due to the school consolidation project that allowed for it (Corbett, 1989; Prochner, 2000).

\section{Kindergarten in the 1970s}

The enrollment in schools was gradually declining in the 1970s mainly due to the low birth rate in Canada after the "baby boom" period of 1946-1961, and Ontario was no exception (Wahlstrom et al, 1980). The mid 1970s were also the years of cutbacks imposed by the provincial government; as a result, some schools were forced to close and lay off teachers (Ontario, Royal Commission on Learning, 1994). 
Wahlstrom's report (Wahlstrom et al., 1980) helps identify some reasons for the declining enrollment in kindergartens. One of them was the lack of continuity in childcare and education services and programs (Wahlstrom et al., 1980). Project CHILDCARE revealed a strong demand for childcare for three- to five-year-olds and "great difficulties encountered by parents seeking good group childcare and those forced to accept second and third choices for children because of the lack of desired care" (Wahlstrom et al., 1980, p. 163). The fragmentation of early childhood programs and services was not meeting the needs of working parents, and the employment of women was steadily increasing. Half-day kindergartens were not an ideal solution, especially since according to Wahlstorm's report (1980), most boards did not wish to provide before- and after-school programs. It is not surprising then, that there was a growing interest in the full day kindergarten program as indicated in the research for the Ministry of Education by Andrew Biemiller (1978). The reasons were mostly academic (to provide "expanded academic and physical educational opportunities for young children") but also the growing childcare needs of working mothers (Biemiller, 1978, p. 3).

Only $30 \%$ of school boards were offering junior kindergarten programs - half of them on a very limited basis and the other half extensively (Wahlstrom et al., 1980). The major limitations to establishing junior kindergartens were financial constraints, the cost of transportation, and the lengthy travel time for young children in some rural boards (Wahlstrom et al., 1980). The decreasing enrollment can also be linked to the debatable value of junior kindergarten and parental attitudes (Wahlstrom et al., 1980). The main goal of junior kindergarten was socialization and the development of language (Ontario's Teachers' Federation, 1973). “Curriculum Guidelines for Junior Kindergarten" from 1973 follows the 1966 Program and states that "the school program should not become highly formalized and devoted to 'reading readiness' because, by its nature, readiness is broad in scope and comprehensive in development" (Ontario's Teachers' Federation, 1973, p. 34). For this reason, junior kindergarten was perhaps perceived by many as not beneficial enough.

At the same time, in both junior and senior kindergartens, there was no consistency in goals and practice, because the Ministry of Education articulated only broad goals for the programs and shifted the responsibility for programming to the local school boards (Wahlstrom et al., 1980; Ministry of Education, 1975). Some school boards had an evident child-centred focus, others were teacher-centred with the goal "to get as many of the class through a readiness workbook before June and perhaps have them reading from a pre-primer as well" (Wahlstrom et al., 1980, p. 70), some were a combination of both and some were "thought to be a babysitting service" (Wahlstrom et al., 1980, p. 61). Only some programs were rich in resource literature that was translated into appropriate goals for a specific age group (Wahlstrom et al., 1980).

Although most children attended regular half-day programs, some school boards were also providing alternate full day junior and senior kindergartens (AFD), as well as 
full day senior kindergarten programs (FD). The FD programs were implemented to provide more academic time for reading, mathematics, writing, and/or bilingual education (Biemiller, 1978). The Ministry of Education funded a study to assess the effects of half-day (HD), AFD, and FD kindergarten programs on children's constitutional capacities, skills, and emotional and behavioural development (Biemiller, 1978). Some results of the study suggest that AFD children (especially in junior kindergarten) and FD senior kindergarten were experiencing stress at school and were more tired at home after being away from home between seven to nine hours (Biemiller, 1978). Although FD programs provided more academic activities, there was no evidence that children were more advanced in the language and academic skills that were assessed (Biemiller, 1978). Therefore, Biemiller (1978) recommended further research "before implementing FD programs for academic reasons on a large scale" (Biemiller, 1978, p. 91). However, he adds

There are a number of other reasons for considering the operation of full day kindergarten programmes including particularly the growing number of working mothers and single parents, and the deficiencies of many home environments (e.g., apartments) for stimulating physical, social, and in some cases, intellectual growth. (Biemiller, 1978, p. 95)

During the same period in the 1970s, multiple entry in junior kindergarten as well as family group kindergartens were experimented with (Wahlstrom et al., 1980). The rationale for the multiple entry program was that children born in the last quarter of the year appeared to be at a disadvantage, competing with peers who were almost a year older (Wahlstrom et al., 1980). The multiple entry program allowed children to start school in September, January, and April, and they could be moved to a higher group when they were ready, without waiting until September (Wahlstrom et al., 1980). However, some financial deterrents involving grants, and subsequent classes not operating in the same way, did not allow the idea to continue (Wahlstrom et al., 1980). The multi-age group kindergarten was chosen by some school boards in Toronto area because of declining enrollment and because educators believed in developmental benefits of a mixed-age group of children between the age 3.5 and 6.5 (Wahlstrom et al., 1980). These classes allowed children to work at their own level in the same class for more than one year without being accelerated or slowed down because of their chronological age.

\section{Kindergarten in the 1980s and 1990s}

In 1985 the "Report of the Early Primary Education Project" (Ministry of Education, 1985) proposed a new approach to early childhood education. It puts less focus on the child and more on societal needs and expectations. Sociocultural changes, like the 
weakening stability of the family, single parenting, and the growing isolation from traditional support systems, created problems for families that the schools were expected to solve. The report points to the results of early compensatory education that are both convincing and promising. Additionally, accumulating evidence indicated that young children have a remarkable learning capacity that educators must take into account because "carefully designed and administered cognitive stimulation early in life can make substantial differences not only to children's intelligence but also to the strengthening of their self-confidence and social competence" (Ministry of Education, 1985, p. 18). The report proposed a new model of early education that would use these opportunities. Findings from the research of the HighScope Educational Research Foundation in Michigan and from the Institute for Developmental Studies at New York University were used to support this proposal (Ministry of Education, 1985). According to these findings, good early childhood education leads to lower delinquency rates later in life, much higher productivity, self-sufficiency, employability, and positive participation in economic life. "These gains lead to substantial economic benefits for the community. The HighScope researchers have calculated that for every $\$ 1,000$ society invests in early primary programs of high quality, the return to society is $\$ 7,000$ " (Ministry of Education, 1985, p. 20). This economic calculation used to support the recommendations is the sign of a new approach to reforms in early childhood education in the 1980s, an approach based on accountability and focused on clear and measurable outcomes, as noted by Bruno-Jofré and Hills (2011). It was consistent with the emerging discourse in English-speaking countries, termed by Peter Moss (2017) "a story of quality and high returns." This discourse, successfully globalized, is based on and submerged in a particular neopositivistic view that the concepts of the natural sciences (objective truth and knowability) as well as their methods (including measurement methods) are applicable to the social sciences (Moss, 2017). When applied to early childhood education, it treats children instrumentally and expects predefined outcomes determined by experts who had researched "what works" and calculated a rate of return on investment (Moss, 2017).

The new proposed model of early education calls for more attention to the value of play in a child's learning and claims to benefit all children, regardless of the socioeconomic status of their families (Ministry of Education, 1985). The child's curriculum should be a lifelong project of exploration and growth, and it should provide continuity between home and school (Ministry of Education, 1985). Yet the report finds kindergartens operating separately from the rest of the school and from services for families and children, with little involvement of parents in the program. The central recommendations made in the report are that junior kindergarten to Grade 3 be organized as an integrated unit, providing continuity in programming, flexibility in progression and entry age, and close links with the families and the community. Another recommendation to the Ministry of Education is to investigate the feasibility of 
introducing extended full day kindergarten as particularly advantageous for some children who are lacking the enriched experiences at home.

In 1989 the Liberal government announced that all school boards in Ontario are required to provide half-day junior and senior kindergarten programs. In 1990 the newly elected NDP government implemented the Liberal's policy and supported it with additional funding for junior kindergarten programs (Karia, 2014). During the early 1990s, research studies were commissioned by the Ministry of Education to prepare for the expansion of kindergarten programs to include junior kindergartens and extended day programs in schools. Despite the Liberal and NDP governments' commitments to introduce junior kindergarten across all school boards in Ontario, in 1995 the new Progressive Conservative government reversed the 1989 policy and announced that school boards do not have to provide junior kindergarten programs, at the same time reducing grants to these programs by 50\% (Karia, 2014). When analyzing this abrupt change, the link should be made between the political ideology represented by the provincial government and educational policy development. The tensions and difficulties in developing kindergarten programs for younger children can be explained by the growing support for neoliberalism with its deregulations, privatizations, and reductions in public spending, as well as its instrumental, calculative, and economistic rationality that was already noticeable in the 1985 "Report of the Early Primary Education Project" (Ministry of Education, 1985). New educational policies were marked by the neoliberal focus on standardization and preparing children for school and employment, treating children as an investment in the future labour market.

This shift in educational goals is evident when the reports and program documents from the 1960s and the 1970s are compared with those from the 1990s. In the former, there is no indication of economic competitiveness. The latter were already framed by the major political and economical changes caused by the end of communism in Europe in 1989 and the emerging faith in neoliberalism and the free market. The global and international pressures are clearly reflected in the 1993 Victoria Declaration which put education and economic globalisation on the national agenda, focusing on standardization and testing (Bruno-Jofré \& Hills, 2011). Bruno-Jofré and Hills (2011) consider the 1994 "For the Love of Learning" report as setting the stage for the new view of education-driven by accountability or evaluation. The report recommended creating a new office-an Office of Learning Assessment and Accountability-which was quickly established by the newly elected Progressive Conservative government led by Mike Harris (Bruno-Jofré \& Hills, 2011). 


\section{8 and 2006 Kindergarten Programs}

In 1998 the new kindergarten program was issued, followed by the revised document in 2006 (Ministry of Education, 1998; Ministry of Education, 2006). The 1998 program was shifting the developmentally oriented kindergarten to a more academic one, with clearly expressed skills that children should gain before they start Grade 1. The updated 2006 program took this shift even further. According to Russell (2011), "a developmental logic frames the purpose of kindergarten as supporting the individual child's social, emotional, and cognitive development, while the academic logic emphasizes academic skills and content" (Russell, 2011, p. 239). The comparison between the two programs illustrates this shift at the accelerated speed.

Both the 1998 and 2006 programs contain specific expectations for different areas of learning (language, mathematics, science and technology, personal and social development, the arts), and the updated program also lists health and physical activity. In both documents, the learning expectations in all these areas are expressed by the word "will" in every section: "By the end of kindergarten, children will: ...." (Ministry of Education, 1998; Ministry of Education, 2006).

The word "will" leaves little if any room for children who may not be developmentally ready to meet these expectations. Although both programs acknowledge that "children develop at different rates and in different ways" (Ministry of Education, 1998, p. 9; Ministry of Education, 2006, p. 2) they further assume that all children will achieve same level of academic skills. "The expectations are not designed to address Junior and Senior Kindergarten separately" (Ministry of Education, 2006, p. 5), but specific examples indicate the two stages of achievement by the words "initially" and "eventually." The 2006 program expanded the learning expectations to 30 pages from eight in 1998 document, with specific sample problems directed by the teacher and examples of how children will respond to them.

\section{Full Day Early Learning Kindergarten}

The growing evidence of the importance of early childhood education, studies showing that $27 \%$ of Ontario children fall significantly behind their peers when they start Grade 1 (Pascal, 2009), UNICEF's data on a number of benchmarks for Early Learning and Care met by country showing Canada at the end of the rank (Pascal, 2009), and the lack of universal childcare and early education programs - all led to the development of proposals to replace the half-day kindergarten with the full day program.

In January 2007, a framework Early Learning for Every Child Today (ELECT) for Ontario early childhood settings was prepared and published by the Best Start Expert Panel on Early Learning (Best Start Expert Panel on Early Learning, 2007). The report does not address the kindergarten program separately, but includes it in the guidelines 
for the consolidated early childhood programs for children from birth to Grade 1, situating children "within the context of a developmental continuum rather than evaluating their performance against age-related expectations," and recognizing that care and learning are inseparable concepts (Best Start Expert Panel on Early Learning, 2007, p. 4).

Similarly, the Report to the Premier by the Special Advisor on Early Learning, Charles E. Pascal (2009) does not refer to kindergarten, but to an early learning program. Pascal was asked to recommend how to best implement full day learning for four- and five-year-olds. He points out that to fully benefit from the full day learning for children of this age, we must develop a continuum of services for children from birth to age 12 (Pascal, 2009). Studies indicate that the most successful countries in providing early childhood services are the ones that integrate education and childcare under one auspice (Pascal, 2009).

Pascal proposed a two-year program for all children who turn four by December 31. This program should include extended before- and after-school programming (for a fee with subsidies available) for children aged six to eight, at the request of at least 15 families in a school. The extended day program would not be an add-on but an integral part of an Early Learning Program, following same pedagogical and curriculum approach, and delivered by qualified educators using the same space and resources. It would eliminate the existing fragmentation of early years services, which was the result of the historic divide between education and childcare. "Separated by legislation, funding, and delivery structures, Kindergarten with its education roots is viewed as contributing to the public good whereas child care is mired in its social welfare status" (Pascal, 2009, p. 16). The curriculum, pedagogical framework, ongoing individual observation and documentation, guidelines for facilities and outdoor spaces, as well as behaviour guidance practices, are recommended to be based on the ELECT document (Pascal, 2009). ELECT should be also adapted in collaboration with Indigenous educators and organizations, to reflect Indigenous content in programming (Pascal, 2009).

The report's title "With Our Best Future in Mind" reveals the "selling features" of the recommended program: "a cost-effective return on our early learning investment [which] will be clear to all Ontario taxpayers" (Pascal, 2009, p. 7). The author further indicates that "public policy commitment to improving children's development will have transformative social and economic effects" (Pascal, 2009, p. 10) by reducing poverty, violence and crime rates, behavioural, emotional, and health problems, and by paying "huge dividends for the success and well-being of individuals and our society. Simply put, there is no wiser investment for our best future" (Pascal, 2009, p. 12). The report uses the results of studies done by world-recognized economists like James Heckman who calculated a 7:1 return on public investment for programs for young children, the HighScope Ypsilanti, Michigan study showing $\$ 17$ savings for every $\$ 1$ spent on the program, or Canadian studies showing a 2:1 payback from developmentally enriched 
early childhood programs (Pascal, 2009). These claims were in line with the common discourse of "quality and high returns" and the growing trend of situating education in relation to economic gains and addressing its instrumental purposes (Bruno-Jofré \& Hills, 2011; Moss, 2017). In this regard, it echoes the 1985 report in quoting the same HighScope study and treating the early childhood education as the instrument to solve some societal problems and compensate vulnerable children from disadvantaged home and community environments.

In 2010, under the Liberal Party leadership in the province, the major expansion of kindergarten was finally materialized. The Legislative Assembly of Ontario directed the Ministry of Education to implement the full day kindergarten in phases from 2010 to 2014 and mandated the management and supervision of early childhood education from the Ministry of Children and Youth Services to the Ministry of Education. Pascal's report "With Our Best Future in Mind" and his recommendations were instrumental in establishing FDELK in Ontario (Karia, 2014).

FDELK is available to all four- and five-year-old children in publicly funded schools across the province. The children go to school all-day every-day from Monday to Friday. School boards are required to offer before- and after-school programs where there is sufficient demand from parents and families; these programs can be operated by third party operators. The 2015 survey showed that $72 \%$ of schools with kindergarten offered on-site before- or after-school care, but only $41 \%$ offered yearround on-site childcare for kindergarten-aged children (People of Education, 2015). The challenges to implementing an integrated and seamless full day program were found in the lack of trained childcare providers and space constraints (People for Education, 2015).

Replacing the half-day kindergarten program with the FDELK changed not only the amount of time children were spending in the school environment, but also the way they were being taught. As Karia (2014) notes, the half-day kindergarten involved more formal teaching and teacher-directed activities that children were expected to complete by the end of each week. This can be explained by teachers' professional preparation, no requirement of specific training for early childhood education, as well as by time restriction (usually 2.5 hours a day) and a pressure to meet all the goals set in the kindergarten curriculum. The FDELK presents a new and unique team-teaching approach to instruction, involving a certified teacher and an early childhood educator in each class with at least 16 students. This new collaborative approach contributed to shifting the learning to less formal, more flexible, and less teacher-directed. The Program document recognizes the role of play in early childhood and states that childinitiated free play, as well as more structured play-based learning, should be integral parts of the classroom.

The curriculum maintains the academic achievement expectations of the previous document (Ontario Ministry of Education, 2006), with The Learning Areas in the Program with specific expectations for the children (Ontario Ministry of Education, 
2010). At the same time, it requires a play-based approach to learning and developmentally appropriate practice (Ontario Ministry of Education, 2010). This dichotomy creates tensions and challenges for teachers who have to negotiate between developmental and academic logics (Pyle, 2013).

In 2014, the Ontario Ministry of Education issued a document "How Does Learning Happen? Ontario's Pedagogy for the Early Years," which paved the way to the revision of the 2010-2011 Program. This document is clearly influenced by Reggio's pedagogy. It states: "When educators are aware of and able to understand and respond to many 'languages' children use to communicate, they give every child a 'voice'” (Ontario Ministry of Education, 2014, p. 41). It recognizes children as "competent, capable of complex thinking, curious, and rich in potential," stresses the importance of the environments in early years, and the need for partnership and collaboration between educators and family to support learning (Ontario Ministry of Education, 2014, p. 6). It recommends using pedagogical documentation, listening to children to learn about them and their experiences, and including their perspectives in co-planning with them and their families (Ontario Ministry of Education, 2014).

This shift toward a Reggio-inspired pedagogy is reflected in the 2016 Kindergarten Program document. It shifts the role of the educator from a "lead knower" to a "lead learner" or co-learner, recognizing that this approach "may require, for some, a shift in mindset and habits. It may prompt a rethinking of theories and practices" (Ontario Ministry of Education, 2016, p. 10). The 2016 program recognizes the benefits of treating children as competent partners in the process of learning (Ontario Ministry of Education, 2016). Other Reggio-influenced pedagogical approaches in the Program include pedagogical documentation, environment as a third teacher, and learning through play and inquiry.

The play-based learning approach is explained over 13 pages of the document, in contrast to the 2010 Program which dedicated three pages to this topic. It further stresses the importance of play, recognizing it as a child's right according to the United Nations Convention on the Rights of the Child and as "essential to the development of children's cognitive, physical, social, and emotional well-being" (Ontario Ministry of Education, 2016, p. 12). Instead of subject areas for learning as in previous programs, the 2016 document uses four frames, or broad areas of learning: belonging and contributing, self-regulation and well-being, demonstrating literacy and mathematic behaviours, and problem solving and innovating (Ontario Ministry of Education, 2016). "The frames reflect the integrated way in which learning occurs during children's play and inquiry in Kindergarten" (Ontario Ministry of Education, 2016, p. 13). 


\section{Conclusion}

Ontario has the distinction of having the longest and the richest history of public kindergarten in Canada. For many decades, Ontario was the only province that embraced the idea of kindergarten as a permanent part of a public education. In the rest of Canada, there was little interest in publicly funded kindergarten until the mid 20th century. Some reasons for the low interest in establishing public kindergartens was the historical division between childcare and education and the role of the private sector in early childhood care and education. Childcare in Canada is treated as a market commodity, defined by the general public as childminding and by the government as a service to support working parents. Yet professionals in the early childhood field define quality childcare as a program that educates as much as it cares (Pascal, 2009). Studies indicate that the most successful countries in providing early childhood services are the ones that integrate education and childcare under one auspice (Pascal, 2009).

The history of kindergarten in Ontario shows that the provincial government has continuously recognized the need for a kindergarten program to be offered to all children as an integral part of public education. The quality and extent of the program, however, has always depended on the dominant political, ideological, and economic currents. The introduction of kindergarten in the public school system was possible owing to the many years of tireless promotion by James Hughes. Maintaining it in the first half of a 20th century was often a struggle. Although over the next decades reports and proposals were commissioned for the best model of early childhood education, no new version of kindergarten was introduced until 2010. These tensions and difficulties in expanding the kindergarten program can be explained by the emerging neoliberalism with its deregulations, privatizations, and reductions in public spending. Viewing the contemporary FDELK from this perspective and using Moss's (2017) arguments, this extended program was possible owing to a recent global policy interest in early childhood education giving early childhood "its current global political legitimacy," and due to a dominant discourse of "quality and high returns" in Anglophone countries.

Although Ontario's kindergarten can be considered a success, the historical perspective is a reminder of past ideas that were lost or forgotten and should be brought back for future consideration when developing educational programs for young children. The analyzed reports on the best model of early years programs do not address kindergarten separately. On the contrary, all of them ("For the Love of Learning," Ontario Royal Commission on Learning, 1994; "ELECT," Best Start Expert Panel on Early Learning, 2007; "With Our Best Future in Mind," Pascal, 2009; "Report of the Early primary Education" Project, Ministry of Education, 1985) recognize that care and education are inseparable concepts and propose integrated and comprehensive programs that include services in all aspects of care, health, nutrition, 
and education for children from birth to at least Grade 1 as the most beneficial for child development. These proposals still need to be advocated for, as early childhood programs and services are still fragmented, many school boards do not offer an integrated seamless day, and most of them do not provide year-round extended care for children attending kindergarten.

\section{References}

Best Start Expert Panel on Early Learning. (2007). Early learning for Every Child Today: Framework for Ontario Early Childhood Settings. Ontario Ministry of Children and Youth Services.

Biemiller, A. (1978). Kindergarten programmes: Effects of Regular Half day, Alternate Full Day, Daily Full Day programmes. Institute of Child Study, University of Toronto. Braudel, F. (1980). On History. The University of Chicago Press. Bruno-Jofré, R., \& Hills, G. (2011). Changing visions of excellence in Ontario school policy: The cases of 'living and learning' and 'for the love of learning.' Educational Theory 61(3), 335-349.

Bruno-Jofré, R., \& Jover, G. (2011). The Pedagogical Creeds of the End of the XIX Century in the United States: The Transatlantic Movement of Ideas and the Readings of John Dewey's Creed in its Intersection with Catholicism. Presented at the Canadian Catholic Historical Association/ American Catholic Historical Association Conference. St. Michael's College, University of Toronto, April 1 and 16, 2011.

Bruno-Jofré, R., \& Jover, G. (2013). El Educando como Sujeto y el Lugar del Juego en el Debate Educativo de Finales del Siglo XIX en Norteamérica. Bordon. Journal of the Sociedad Espanola de Pedagogia, Spain, 65 (1), pp. 21-37.

Carter, B. M. (1966). James L. Hughes and the gospel of education. [Doctoral dissertation]. University of Toronto.

Corbett, B. (1989). A century of Kindergarten Education in Ontario, 1887 to 1967. The Froebel Foundation.

Friendly, M., Larsen, E., Feltham, L., Grady, B., Forer, B., \& Jones, M. (2018). Early Childhood Education and Care in Canada 2016. Childcare Resource and Research Unit.

Froebel, F. (1908). The Education of man. D. Appleton and Company. Hughes, J. (1890). Personal letter to a young teacher. Toronto: [s.n.]. Hughes, J. (1897). Froebel's educational laws for all teachers. D. Appleton and Company.

Johnson, F. H. (1968). A brief history of Canadian education. McGraw-Hill Company of Canada. 
Karia, E. (2014). The full day kindergarten classroom in Ontario: Exploring play-based learning approach and its implications for child development. [Doctoral Thesis]. University of Toronto.

Mathien, J. (2001). Children, families, and institutions in Late 19th and early 20th Century Ontario. [Master's thesis]. University of Toronto.

McMurrich, W. B., \& Roberts, H. N. (1894). The school law of Ontario: Comprising the Education Dept. Act, 1891, the Public Schools Act, 1891, the act respecting truancy and compulsory school attendance, the High Schools Act, 1891 and the amending acts of 1892 and 1893: with notes of cases bearing thereon, the regulations of the Education Department, forms, etc. Goodwin.

Ministry of Education. (1975). The Formative Years. Circular P1J1. Provincial curriculum policy for the primary and junior divisions of the public and separate schools of Ontario. Author.

Ministry of Education. (1985). Report of the early primary education project. Author.

Ministry of Education. (1998). The kindergarten program. Author.

Ministry of Education. (2006). The kindergarten program. Revised. Author.

Moss, P. (2017). Power and resistance in early childhood education: From dominant discourse to democratic experimentalism. Journal of Pedagogy 8(1), 1-32.

Ontario Department of Education. (1908). Syllabus of studies and regulations for kindergartens. L.K. Cameron, Printer to the King's Most Excellent Majesty.

Ontario Department of Education. (1944). Programme for junior and senior kindergarten and kindergarten primary classes of the public and separate schools. Queen's Printer for Ontario.

Ontario Department of Education. (1966). Kindergarten.

Ontario Department of Education. (1968). Living and learning: The report of the provincial committee on aims and objectives in the schools of Ontario. Author.

Ontario Ministry of Education. (2010). The Full-Day Early Learning-Kindergarten Program. Queen's Printer of Ontario.

Ontario Ministry of Education. (2014). How does learning happen? Ontario's pedagogy for the early years. Queen's Printer for Ontario.

Ontario Ministry of Education. (2016). The kindergarten program. Queen's Printer of Ontario.

Ontario Royal Commission on Learning. (1994). For the love of learning: Report of the royal Commission on Learning. Author.

Ontario Teachers' Federation. (1973). Curriculum guidelines for junior kindergarten. (R. Stasios, Ed.).

Pascal, C. (2009). With Our Best Future in Mind. Implementing Early Learning in Ontario. Queen's Printer for Ontario.

People for Education. (2015). Ontario's Schools: The Gap between Policy and Reality. Author 
Prochner, L. (2009). A history of early childhood education in Canada, Australia, and New Zealand. UBC Press.

Prochner, L., \& Howe, N. (eds). (2000). Early Childhood Care and Education in Canada. UBC Press.

Pyle, A. (2013). Listening to the voices in the garden: The enactment of curriculum in contemporary kindergarten. [Doctoral thesis]. Queen's University.

Russell, J. L. (2011). From child's garden to academic press: The role of shifting institutional logics in redefining kindergarten education. American Educational Research Journal 48(2) 236-267.

Shapiro, M. (1983). Child's garden. The kindergarten movement from Froebel to Dewey. Pennsylvania State University Press.

Skinner, Q. (1969). Meaning and Understanding in the History of Ideas. History and Theory 8(1), 3-53.

Wahlstrom, M. W., Delaney-Donohue, S., Clandinin, J., \& O’Hanley, J. (1980). Early childhood education. The Minister of Education.

Weber, E. (1969). The kindergarten. Its encounter with educational thought in America. Teachers College, Columbia University. 